DOI: $10.2478 /$ lpts-2020-0008

\title{
THE JOINT SLR (OPTICAL RANGE) AND \\ RADAR-VLBI SATELLITE OBSERVATIONS USING VIRAC RADIO TELESCOPE RT32, RT16 AND SLR STATION RIGA
}

\author{
K. Skirmante ${ }^{1 *}$, N. Jekabsons ${ }^{1,2}$, K. Salmins ${ }^{3}$, \\ V. Bezrukovs ${ }^{1}$, M. Nechaeva ${ }^{4}$ \\ ${ }^{1}$ Engineering Research Institute \\ "Ventspils International Radio Astronomy Centre", \\ Ventspils University of Applied Sciences, \\ 101 Inzenieru Str., Ventspils, LV-3601, LATVIA \\ ${ }^{2}$ Department of Physics and Mathematics, University of Latvia, \\ 19 Raina Blvd., Riga, LV-1586, LATVIA \\ ${ }^{3}$ Institute of Astronomy, University of Latvia, \\ 19 Raina Blvd., Riga, LV-1586, LATVIA \\ ${ }^{4}$ Moscow Power Engineering Institute (OKB MEI), \\ 14 Krasnokazarmennaya Str., Moscow, 111250, RUSSIA \\ *e-mail: karina.krinkele@venta.lv
}

Joint VLBI and SLR satellite tracking is a novel tracking approach to explore potential applications and to work out common procedures to coordinate observations between astronomical observatories in Latvia. Global Navigation Satellite System (GNSS) satellites equipped with laser retroreflectors have been chosen as test targets because they are accessible by both measuring techniques - satellite laser ranging (SLR) and Very Long Base Interferometry (VLBI).

The first Joint SLR and VLBI observations of selected GNSS satellites using three of Latvian large-scale astronomical utilities - VIRAC radio telescopes RT32 and RT16 (Ventspils International Radio Astronomy Centre of Ventspils University of Applied Sciences) with L band receivers and SLR station Riga (Institute of Astronomy of University of Latvia) were obtained in 2016 (NKA16) and 2017 (NKA41 and NKA42).

Keywords: VLBI, SLR, Joint observations, GNSS satellites 


\section{INTRODUCTION}

Satellite Laser Ranging (SLR) is a method of measuring distances to the satellites using very short laser pulses. At the SLR station, a very short laser pulse is generated, transmitted to the satellite, and reflected back to the station, where it is detected. A high precision event timer - using time and standard frequency derived from a specially dedicated GPS receiver or from primary time standard like caesium clock or hydrogen maser - measures the time of flight of the laser pulse with a precision of about 3 ps. Using the known velocity of light, one can thus determine the distance to the satellites - from a few hundred $\mathrm{km}$ up to more than $20,000 \mathrm{~km}-$ with subcentimeter accuracy.

The method of Very Long Baseline Interferometry (VLBI), one of the most powerful approaches used in radio astronomy, allows obtaining accurate determination of coordinates of radio sources. Since the 1980s, VLBI method is successfully applied for angular coordinate determination of artificial Earth satellites and interplanetary space stations with the precision $0.01-0.03$ arcsec in single measurements. Since neither distance nor radial velocity of the object can be measured with VLBI method alone, it solves the navigation task only partly. These parameters can be obtained with space navigation methods (passive radar) or active radar. The combination of both radar methods can be used as radar-VLBI method. The space navigation methods apply the ranging and Doppler measurements using the on-board transmitters.

A radar VLBI method has been used for the refinement of the orbit parameters of space debris fragments, near-Earth asteroids and evaluation of rotation of planets [5]. It supplements the traditional radar methods with the interferometric reception of a ground-based transmitter signal reflected from the object [3]. Such an addition allows for measurements of distances, as well as for radial velocity, angle and angular velocity of the object. By the exploitation of several distant receiver stations of reflected radar signal, the radar VLBI has a potential for very high accuracy. In theory, the radar VLBI may yield all the motion parameters required for the formulation of a Newtonian orbital solution in a single measurement.

Since 2001, a large number of experiments on radar VLBI of objects in the near Earth space have been carried out with radio telescopes in Ukraine, Russia, Italy, China, Latvia, etc. [4]. One of such experiments was VLBI international experiment on radio location of the asteroid 2012 DA14 [1], which was organized on 15-16 February 2013 during its flyby close to the Earth. The aim of observations was to investigate and specify orbital parameters of the asteroid, as well as to evaluate its rotation period and some other characteristics. The asteroid was irradiated by the 5010.024 MHz frequency signal (radar RT-70, Evpatoria, Ukraine), whereas the echo signals were received by the radio telescopes RT-32 in Irbene (Ventspils, Latvia) and Medicina (Italy) in VLBI regime. A series of observations was implemented for different distances between the Earth and the asteroid (from $30000 \mathrm{~km}$ to 250000 $\mathrm{km})$. The reflected signals were successfully received by the both VLBI-stations. Processing of the recorded signals allowed measuring the Doppler frequency and 
interference frequency in order to improve the calculation of the radial and angular velocity of the asteroid. Processing and interpretation of the data were performed at Ventspils International Radio Astronomy Centre and Lobachevsky State University of Nizhny Novgorod, which was a collaboration partner of DA14 experiment.

\section{GOAL OF THE COMBINATION OF VLBI AND SLR METHODS}

The combination of SLR and VLBI is a novel approach; it is potentially reliable and accurate for large-scale NEO observations and space geodesy. Our long-term goal is to develop the methodology for potentially accurate and reliable measurements of all the coordinates and velocities in a few or even single observation(s). The aim of combining several optical and radar methods is mainly the reliability of the composite method. Radar methods (active and passive radar as well) yield an acceptable range and radial velocity resolution while VLBI allows for angle and angular rate information, these are all-weather measurements. SLR allows for instantaneous range measurements of centimetre or millimetre level precision; however, superior accuracy in the line of sight comes with constraints on weather conditions. Complementary SLR and radar-VLBI potentially give high precision tracking of space debris at the all deorbiting stages. An active spacecraft can be guided and real time traced with the mentioned method. In the future, combination of these technologies may serve as a basis for determination of ongoing dynamic processes on the Earth, maintenance of precise parameters of the coordinate system on the global scale and forecast of eventual risks and cataclysms in the future. Observation of critical or unique events in the near-Earth space is possible with the best available accuracy when methods are combined. Data processing from two independent simultaneous measurements (for example, with specific Kalman filters) may allow ruling out human errors or other sporadic error sources. Thus, reliability of overall measurement can be improved considerably even if actual accuracy is dictated by more accurate instruments (SLR).

\section{EXPERIMENTAL PART}

SLR and passive radar-VLBI observations of transmitting geodetic satellites (GPS and GLONASS) were carried out in 2016 and 2017. The aim of the observations was to develop the technology by means of accurate measurements of the deviations in orbital parameters of the known satellites. Two different technologies - SLR and VLBI - were combined, and simultaneous observations took place at the same time on the same objects. Thus, in 2016 SLR station in Riga and three VLBI stations (radio telescopes RT-16 and RT-32 in VIRAC of VUC and UNN (RT2) in NIRFI) were used in NKA16 experiments and more than 25 GPS and GLONASS satellites were tracked. On 23-24 September 2017, SLR station Riga and both VIRAC radio telescopes were used in NKA41 and NKA42 experiments. The example of NKA41 observation schedule plan is shown in Table 1. 
NKA41 Observation Schedule Plan

\begin{tabular}{|c|c|c|c|}
\hline $\begin{array}{l}\text { Start } \\
\text { time } \\
\text { of scan } \\
\text { (UTC) }\end{array}$ & $\begin{array}{c}\text { End time } \\
\text { of scan } \\
\text { (UTC) }\end{array}$ & $\begin{array}{c}\text { Observed } \\
\text { object }\end{array}$ & $\begin{array}{c}\text { Sky } \\
\text { frequency, } \\
\mathrm{MHz}\end{array}$ \\
\hline $17: 45$ & $17: 55$ & CASA & 1602.5625 \\
\hline $18: 00$ & $18: 30$ & $\begin{array}{c}\text { Cosmos } \\
36111 / \\
\text { Glonass } \\
116\end{array}$ & 1602.5625 \\
\hline $18: 35$ & $18: 40$ & CASA & 1575 \\
\hline $18: 45$ & $19: 15$ & $\begin{array}{c}\text { Galileo } \\
40890 \text { / } \\
\text { Galileo } \\
206\end{array}$ & 1575 \\
\hline $19: 20$ & $19: 25$ & CYGNUSA & 1602 \\
\hline $19: 30$ & $20: 10$ & $\begin{array}{c}\text { Cosmos } \\
41554 \text { / } \\
\text { Glonass } \\
136\end{array}$ & 1602 \\
\hline $20: 05$ & $20: 10$ & CYGNUSA & 1599.75 \\
\hline $20: 15$ & $20: 45$ & $\begin{array}{c}\text { Cosmos } \\
39155 / \\
\text { Glonass } \\
131\end{array}$ & 1599.75 \\
\hline
\end{tabular}

\begin{tabular}{|c|c|c|c|}
\hline $\begin{array}{l}\text { Start } \\
\text { time } \\
\text { of scan } \\
\text { (UTC) }\end{array}$ & $\begin{array}{l}\text { End time } \\
\text { of scan } \\
\text { (UTC) }\end{array}$ & $\begin{array}{c}\text { Observed } \\
\text { object }\end{array}$ & $\begin{array}{c}\text { Sky } \\
\text { frequency, } \\
\text { MHz }\end{array}$ \\
\hline $20: 50$ & $20: 55$ & CYGNUSA & 1602.5625 \\
\hline 21:00 & $21: 30$ & $\begin{array}{c}\text { Cosmos } \\
36111 / \\
\text { Glonass } \\
116\end{array}$ & 1602.5625 \\
\hline $21: 35$ & $21: 40$ & $3 \mathrm{C} 123$ & 1599.75 \\
\hline $21: 45$ & $22: 15$ & $\begin{array}{c}\text { Cosmos } \\
39155 / \\
\text { Glonass } \\
131\end{array}$ & 1599.75 \\
\hline $22: 20$ & $22: 25$ & $3 \mathrm{C} 123$ & 1602 \\
\hline 22:30 & 23:00 & $\begin{array}{c}\text { Cosmos } \\
41554 / \\
\text { Glonass } \\
136\end{array}$ & 1602 \\
\hline 23:05 & $23: 10$ & $3 \mathrm{C} 123$ & 1575 \\
\hline $23: 15$ & $23: 45$ & $\begin{array}{c}\text { Galileo } \\
\text { 40890/ } \\
\text { Galileo 206 } \\
\end{array}$ & 1575 \\
\hline $23: 50$ & 23:55 & $3 \mathrm{C} 123$ & 1575 \\
\hline
\end{tabular}

Observation and Data Processing in RT32 and RT16 Sites

The $\mathrm{L}$ band receivers were used in both stations and data were recorded with $8 \mathrm{MHz}$ bandwidth and LCP (Left Circular Polarization) in VDIF formats using FlexBuff (at RT32) and Mark5 (at RT16) recorders.

3C123, CASA, CYGNUSA objects were included in the schedule for radio telescopes RT32 and RT16 calibration purpose only. Each scan of observation was divided into two parts - with duration of 14 min and 15 min each.

The data processing was carried out using KANA correlator (developed in VIRAC). KANA was designed as a software correlator (ANSI C programming language with POSIX compatibility). Text files in JSON (JavaScript Object Notation) format were used for parametric control of the correlator routines. As for observation data, KANA could process NRFI, and MARK5 a, b data formats. The reader of more recent VDIF data format was added to KANA with the aim of data processing during NKA experiments in 2016. 
Satellite laser ranging schedule usually gives tracking priorities according to ILRS settings for a particular time period. In this case, the GNSS satellites of Ventspils list were given higher priority. To obtain a valid measurement, at least three to five normal points are required. Each normal point or compressed range for GNSS satellites takes five minutes to complete. The data processing was performed according to the ILRS standard procedures. The obtained results are provided in Table 2.

Table 2

The Results of Data Processing in SLR Station Riga Site

\begin{tabular}{|c|c|c|c|c|c|c|}
\hline Satellite & Start & Stop & $\begin{array}{l}\text { Track time } \\
\quad(\mathrm{sec})\end{array}$ & $\begin{array}{l}\text { Number } \\
\text { of normal } \\
\text { points }\end{array}$ & $\begin{array}{c}\text { Normal } \\
\text { point RMS } \\
\text { (ps) }\end{array}$ & $\begin{array}{c}\text { Overlap } \\
\text { with VLBI } \\
(\%)\end{array}$ \\
\hline glonass 116 & $\begin{array}{c}9 / 23 / 2017 \\
20: 31\end{array}$ & $\begin{array}{c}9 / 23 / 2017 \\
21: 21\end{array}$ & 2449.7 & 9 & 90.66 & 100 \\
\hline glonass 131 & $\begin{array}{c}9 / 23 / 2017 \\
21: 40\end{array}$ & $\begin{array}{c}9 / 23 / 2017 \\
22: 15\end{array}$ & 2008.1 & 8 & 180.66 & 100 \\
\hline glonass 136 & $\begin{array}{c}9 / 23 / 2017 \\
22: 35\end{array}$ & $\begin{array}{c}9 / 23 / 2017 \\
22: 45\end{array}$ & 502.1 & 3 & 25.9 & 40 \\
\hline galileo205 & $\begin{array}{c}9 / 24 / 2017 \\
19: 22\end{array}$ & $\begin{array}{c}9 / 24 / 2017 \\
19: 29\end{array}$ & 145.2 & 2 & 27 & 100 \\
\hline glonass136 & $\begin{array}{c}9 / 24 / 2017 \\
19: 04\end{array}$ & $\begin{array}{c}9 / 24 / 2017 \\
19: 45\end{array}$ & 2439 & 7 & 118.53 & 40 \\
\hline glonass 131 & $\begin{array}{c}9 / 24 / 2017 \\
20: 20\end{array}$ & $\begin{array}{c}9 / 24 / 2017 \\
20: 39\end{array}$ & 810.7 & 4 & 143.35 & 100 \\
\hline glonass 107 & $\begin{array}{c}9 / 24 / 2017 \\
22: 35\end{array}$ & $\begin{array}{c}9 / 24 / 2017 \\
23: 29\end{array}$ & 2912.5 & 7 & 98.14 & 0 \\
\hline glonass 102 & $\begin{array}{c}9 / 25 / 2017 \\
1: 47\end{array}$ & $\begin{array}{c}9 / 25 / 2017 \\
2: 11\end{array}$ & 1336.2 & 5 & 71.98 & 0 \\
\hline galileo206 & $\begin{array}{c}9 / 25 / 2017 \\
2: 52\end{array}$ & $\begin{array}{c}9 / 25 / 2017 \\
3: 01\end{array}$ & 286.3 & 2 & 241.15 & 0 \\
\hline
\end{tabular}

During two consecutive nights, there were four sets obtained, which at least partially overlapped with VLBI sessions. Table 3 shows the obtained SLR normal point precision estimates with respect to GNSS orbits as given by GOVUS online tools from Wrozlaw University [7]. 
The Obtained SLR Normal Point Precision Estimates with Respect to GNSS Orbits

\begin{tabular}{|l|c|c|c|}
\hline $\begin{array}{l}\text { Normal point } \\
\text { date/time }\end{array}$ & Satellite & $\begin{array}{c}\text { sat_ } \\
\text { prn }\end{array}$ & $\begin{array}{c}\text { residual } \\
\text { (mm })\end{array}$ \\
\hline 9/23/2017 20:37 & Glonass-136 & R11 & -1.4 \\
\hline 9/23/2017 20:43 & Glonass-136 & R11 & -10 \\
\hline 9/23/2017 20:46 & Glonass-136 & R11 & 11.3 \\
\hline 9/23/2017 19:41 & Glonass-131 & R02 & -15.2 \\
\hline 9/23/2017 19:48 & Glonass-131 & R02 & -76.3 \\
\hline 9/23/2017 19:52 & Glonass-131 & R02 & -19.1 \\
\hline 9/23/2017 19:59 & Glonass-131 & R02 & -9.1 \\
\hline 9/23/2017 20:03 & Glonass-131 & R02 & -9.9 \\
\hline 9/23/2017 20:08 & Glonass-131 & R02 & -29.6 \\
\hline 9/23/2017 20:12 & Glonass-131 & R02 & -11.6 \\
\hline 9/23/2017 20:15 & Glonass-131 & R02 & 40.4 \\
\hline 9/23/2017 18:34 & Glonass-116 & R01 & -42.5 \\
\hline 9/23/2017 18:36 & Glonass-116 & R01 & -1.4 \\
\hline 9/23/2017 18:42 & Glonass-116 & R01 & -36.2 \\
\hline 9/23/2017 18:47 & Glonass-116 & R01 & -15.9 \\
\hline 9/23/2017 18:54 & Glonass-116 & R01 & -18.3 \\
\hline 9/23/2017 18:59 & Glonass-116 & R01 & -44.5 \\
\hline 9/23/2017 19:00 & Glonass-116 & R01 & -17.3 \\
\hline 9/23/2017 19:07 & Glonass-116 & R01 & 35.5 \\
\hline 9/23/2017 19:14 & Glonass-116 & R01 & -75.1 \\
\hline 9/24/2017 18:24 & Glonass-131 & R02 & -53 \\
\hline 9/24/2017 18:27 & Glonass-131 & R02 & -21.3 \\
\hline 9/24/2017 18:33 & Glonass-131 & R02 & -29.1 \\
\hline
\end{tabular}

\begin{tabular}{|l|l|l|c|}
\hline $\begin{array}{l}\text { Normal point } \\
\text { date/time }\end{array}$ & Satellite & $\begin{array}{l}\text { sat_ } \\
\text { prn }\end{array}$ & $\begin{array}{c}\text { residual } \\
\text { (mm })\end{array}$ \\
\hline 9/24/2017 18:37 & Glonass-131 & R02 & -59.4 \\
\hline 9/24/2017 17:04 & Glonass-136 & R11 & -24.1 \\
\hline 9/24/2017 17:07 & Glonass-136 & R11 & -22.1 \\
\hline 9/24/2017 17:12 & Glonass-136 & R11 & -27.3 \\
\hline 9/24/2017 17:34 & Glonass-136 & R11 & -19 \\
\hline 9/24/2017 17:38 & Glonass-136 & R11 & -25.7 \\
\hline 9/24/2017 17:43 & Glonass-136 & R11 & -5.1 \\
\hline 9/24/2017 17:45 & Glonass-136 & R11 & -12.5 \\
\hline 9/24/2017 17:23 & Galileo-205 & E24 & 46.2 \\
\hline 9/24/2017 17:25 & Galileo-205 & E24 & -15.5 \\
\hline 9/24/2017 20:37 & Glonass-107 & R13 & 8.2 \\
\hline 9/24/2017 20:42 & Glonass-107 & R13 & -29.3 \\
\hline 9/24/2017 20:46 & Glonass-107 & R13 & -0.3 \\
\hline 9/24/2017 20:52 & Glonass-107 & R13 & -22.8 \\
\hline 9/24/2017 20:55 & Glonass-107 & R13 & -15 \\
\hline 9/24/2017 21:24 & Glonass-107 & R13 & 5.2 \\
\hline 9/24/2017 21:26 & Glonass-107 & R13 & 1.9 \\
\hline 9/24/2017 23:49 & Glonass-102 & R15 & -38.9 \\
\hline 9/24/2017 23:52 & Glonass-102 & R15 & -29.6 \\
\hline 9/24/2017 23:55 & Glonass-102 & R15 & -26.8 \\
\hline 9/25/2017 00:07 & Glonass-102 & R15 & -36.8 \\
\hline 9/25/2017 00:11 & Glonass-102 & R15 & -68.6 \\
\hline 9/25/2017 00:56 & Galileo-206 & E30 & 79.3 \\
\hline 9/25/2017 01:01 & Galileo-206 & E30 & 902.4 \\
\hline
\end{tabular}

\section{CONCLUSIONS}

Work by joint tracking procedure implementation using SLR and VLBI technologies was started in 2016 to organise NKA16 (2016), NKA41 and NKA42 (2017) observations using VIRAC radio telescopes RT32 and RT16 and SLR station Riga. Unfortunately, NKA16 (2016) experiment was not successful due to technical issues of RT16 and RT32 related to clock synchronization and registration technologies and due to unsuitable weather conditions (rain and fog) for SLR station. NKA41 and NKA42 (both implemented in 2017) experiments were successfully organised and managed for both VIRAC radio telescopes RT32 and RT16 and SLR station Riga. In NKA41 experiment, all of the satellites were successfully observed by RT32 and RT16 and three of the four satellites were successfully observed by SLR station Riga. In NKA42 experiment, all satellites were observed in all included 
stations. It gives a great probability to verify results from data processing of both methods - SLR and radar VLBI, respectively.

Potential applications for joint SLR and VLBI observations were identified. Chinese Atmospheric density detection and Precise Orbit Determination (APOD) satellite tracking could be done using joint SLR and VLBI observation. VLBI radio telescopes can be used in an ideal fashion to link the dynamic reference frames of the satellite with terrestrial and, most importantly, to the celestial reference frame as defined by the positions of quasars [6]. Triggered measurements will be performed using joint optical and radar tracking. The main idea of these measurements is a rapid reaction on the near-Earth space to unexpected events such as satellite collisions, identification of unexpected celestial body, etc. It is possible to develop a limited rapid triggered response capability of the combined SLR-VLBI methodology, including protocol and software development for this purpose. Several space geodesy applications can be developed using the results of the joint SLR and VLBI observations.

Possibilities of further research areas of complementary SLR and radar-VLBI methods: establishing data formats, uniform NEO trajectory description, pointing software, common protocol and session schedule generation, data processing method development, including Kalman type filters, resolution of spatial directions. There are possibilities to develop the mobile VLBI station. Design of the mobile VLBI station will be based on the existing design of ionosphere receiver already developed by the team and deployed on VIRAC RT-32. Single beam-parking mode of operation is specified for the mobile station (no tracking). Live correlation of radar VLBI data (reVLBI) could be developed and implemented in complementary SLR and radarVLBI system.

\section{ACKNOWLEDGEMENTS}

The present research has partially been supported by the National Research Programme of Latvia (project "Multifunctional Materials and Composites, Photonics and Nanotechnology (IMIS2)"; sub-project No. 1.4 "Preparation of the Instrument of Near Earth Object Observation for Safe Cosmic Space Ensuring”).

\section{REFERENCES}

1. Nechaeva, M., Antipenko, A., Bezrukov, D., Bezrukovs, Vl., Dementjev, A., Dugin, N., ... \& Voytyuk, V. (2013). First Results of the VLBI Experiment on Radar Location of the Asteroid 2012 DA14. Baltic Astronomy, 22, 341-346.

2. Bezrukovs, Vl., Bleiders, M., Orbidans, A., \& Bezrukovs, D. (2016). Broadband Receiving Systems for 4.5-8.8 Ghz Radio Astronomical Observations at Irbene Radio Telescopes RT32 and RT16. Space Research Review, 4, 62-76. ISBN 978-9984-48-0537

3. Molotov, I.E., Volvach, A.E., Konovalenko, A.A., Falkovich, I.S., Litvinenko, L.N., Negoda, A.A., ... \& Liu, X. (2004). International Experiments on Development of VLBI Radar Method for Research of Near-Earth Bodies. Kosmichna Nauka i Tekhnologiya, 10 $(2 / 3), 87-92$. 
4. Molotov, I., Nechaeva, M., Falkovich, I., Konovalenko, A., Agapov, Vr., Tuccari, G., ... \& Bezrukov, D. (2008). Astrometry of the Solar System Bodies with VLBI Radar. In the 5th General Meeting of the International VLBI Service for Geodesy and Astrometry. Measuring the Future (pp. 9-10), 2-6 March 2008, St. Petersburg, Russia. ISBN 978-502-025332-2

5. Molotov, I., Konovalenko, A., Agapov, V., Sochilina, A., Lipatov, B., Molotov, E., \& Gorshenkov, Y. (2002). Detection of Space Debris with VLBI Radar Technique. In 34th COSPAR Scientific Assembly, the Second World Space Congress, 10-19 October 2002, Houston, TX, USA.

6. Tang, G., Sun, J., Li, X., Liu, S., Chen, G., Ren, T., \& Wang, G. (2016). APOD Mission Status and Observations by VLBI. In International VLBI Service for Geodesy and Astrometry 2016 General Meeting Proceedings: "New Horizons with VGOS" (pp. 363 367).

7. Zajdel, R., Sosnica, K., \& Bury, G. (2017). A New Online Service for the Validation of Multi-GNSS Orbits Using SLR. Remote Sens., 9 (10), 1049. https://doi.org/10.3390/ rs9101049

8. International Laser Ranging Service. (n.d.). CRD Format Overview, Version V1.01. Available at https://ilrs.cddis.eosdis.nasa.gov/data_and_products/formats/crd.html 


\title{
APVIENOTIE SLR (OPTISKĀ DIAPAZONA) UN \\ RADARA VLBI (RADIO DIAPAZONA) SATELITTU \\ NOVĒROJUMI, IZMANTOJOT VSRC RADIOTELESKOPUS \\ RT32 UN RT16 UN SLR STACIJU RĪGA
}

\author{
K. Šķirmante, N. Jēkabsons, K. Salmiņš, \\ Vl. Bezrukovs, M. Nečaeva
}

Kopsavilkums

Divu astronomisku tehniku apvienojums - ḷoti garas bāzes līnijas interferometriju (VLBI) un satelītu lāzerlokāciju (SLR) - ir jauna metode, lai veiktu satellītnovērošanu. Kopīgiem novērojumiem ir nepieciešams izstrādāt vienotas novērojumu procedūras, lai koordinētu novērojumus starp vairākām astronomiskajām novērošanas stacijām Latvijā.

Globālās navigācijas satelītu sistēmas (GNSS) satelīti, kas aprīkoti ar lāzeru atstarotājiem, tika izvēlēti kā noverojumu mērķavoti, jo tos var novērot ar abām novērojumu metodēm - SLR un VLBI.

2016. gadā (NKA41) un 2017. gadā (NKA16 un NKA42) tika veikti pirmie apvienotie SLR un VLBI novērojumi, novērojot izvēlētos GNSS satelītus un izmantojot trīs lielmēroga astronomiskos instrumentus - VSRC radioteleskopus RT32 un RT16 (Ventspils Augstskolas Inženierpētniecības institūts "Ventspils Starptautiskais radioastronomijas centrs") ar L-frekvenču joslas uztvērējiem un SLR staciju Rīga (Latvijas Universitātes Astronomijas institūts).

Atslēgas vārdi: VLBI, SLR, vienotie noverrojumi, GNSS satelīti 